\title{
PENGARUH PERUBAHAN ARUS KAS YANG DIMODERASI OLEH KORELASI SERIAL DALAM PERUBAHAN ARUS KAS DALAM MEMPREDIKSI AKRUAL
}

\section{(Studi Empiris pada Perusahaan Manufaktur yang Terdaftar di Bursa Efek Indonesia} Tahun 2016-2018)

\author{
Nurjannah ${ }^{1}$, Nurzi Sebrina ${ }^{2}$ \\ ${ }^{1}$ Alumni Jurusan Akuntansi Fakultas Ekonomi Universitas Negeri Padang \\ ${ }^{2}$ Jurusan Akuntansi Fakultas Ekonomi, Universitas Negeri Padang \\ *Korespondensi: nurjannahina@gmail.com
}

\begin{abstract}
Absctract: The purpose of this study was to examine the effect of cash flow change serial correlation in moderating the relationship of cash flow change and accruals. This study is classified as causative research. The population in study are manufacturing companies listed on the Indonesia Stock Exchange of period 2016 to 2018. By using purposive sampling method, there were 43 companies as the research's sampel. The type of data used is secondary data obtained from the official site of the Indonesia Stock Exchange and company's official website. Used is panel regression analysis. The result indicate that cash flow changes has negative and siginificant effect on accrual, but cash flow changes serial correlation is not able to strengthen or weaken the relationship between cash flow changes and accrual.
\end{abstract}

Keyword: Cash flow changes; cash flow changes serial corelation; accrual.

How to cite (APA $6^{\text {th }}$ style):

Nurjannah, \& Sebrina, Nurzi. (2020). Pengaruh Perubahan Arus Kas yang Dimoderasi oleh Korelasi Serial dalam Perubahan Arus Kas dalam Memprediksi Akrual (Studi Empiris pada Perusahaan Manufaktur yang Terdaftar di Bursa Efek Indonesia Tahun 2016-2018). Jurnal Eksplorasi Akuntansi, 2(3), Seri B, 3050-3066.

\section{PENDAHULUAN}

Di era perekonomian sekarang, perusahaan dituntut untuk bisa bersaing dengan perusahaanperusahaan yang lain, baik itu yang berada di negara yang sama atau berada di negara yang berbeda. Salah satu cara yang dapat dilakukan oleh perusahaan untuk bersaing dengan perusahaan lain adalah dengan memberikan informasi tentang perusahaan mereka kepada para pemangku kepentingan perusahaan. Informasi yang diungkapkan tersebut salah satunya dimuat dalam laporan keuangan perusahaan yang disusun oleh manajemen perusahaan.

Manajemen (agent) dalam menyusun laporan keuangan perusahaan menggunakan asumsi-asumsi dasar yang berlaku dalam akuntansi. Asumsi dasar digunakan dalam penyusunan laporan keuangan untuk menjadi konsep dasar yang melandasi penyusunan laporan keuangan. 
Asumsi dasar yang digunakan dalam proses penyusunan laporan keuangan salah satunya adalah asumsi akrual. Asumsi akrual memberikan gambaran tentang pengaruh transaksi dan peristiwa lain, keadaan sumber daya pelaporan entitas ekonomi, dan klaim pada periode dimana transaksi ekonomi tersebut terjadi, walaupun penerimaan dan pembayaran kas terjadi dalam periode yang berbeda. Konsep akrual mencerminkan laporan sumber daya ekonomi perusahaan baik yang telah dimiliki atau yang berpotensi menjadi sumber daya ekonomi entitas, karena pada dasarnya akuntansi hanya menyajikan informasi keuangan masa lampau (historical cost). Penyajian informasi masa lampau (historical cost) saja akan menjadi kritik tersendiri bagi akuntansi, di mana sulit melihat prediksi masa depan perusahaan hanya dengan mengandalkan laporan keuangan yang berbasis historical cost (Suwardjono 2005:358).

Akrual seringkali didasarkan pada asumsi dan estimasi yang jika salah, harus diperbaiki dalam akrual dan pendapatan masa depan. Misalnya, jika penerimaan bersih dari piutang kurang dari perkiraan semula, maka entri berikutnya mencatat baik uang tunai yang dikumpulkan dan koreksi kesalahan estimasi. Dechow dan Dichev (2002) berpendapat bahwa kesalahan estimasi dan koreksi selanjutnya adalah noise yang mengurangi peran manfaat dari akrual. Kesalahan estimasi pada akrual ini merupakan faktor yang mengurangi kualitas akuntansi dan laporan keuangan yang disajikan oleh perusahaan. Untuk mengurangi kesalahan estimasi yang ada pada akrual, Dechow et al. (1998) memodelkan pendapatan, arus kas operasi, dan akrual untuk memprediksi akrual modal kerja dan arus kas masa depan, serta menjelaskan sifat rangkaian waktu dari pendapatan, arus kas, dan akrual. Model Dechow (1998) termasuk piutang, persediaan, dan hutang yang ditunjukkan secara empiris sebagai akrual modal kerja yang paling penting dan menunjukkan bahwa akrual adalah fungsi dari perubahan penjualan saat ini dan sebelumnya.

Analisis Dechow (1998) menunjukkan bahwa prediksi akrual dapat didasarkan pada perubahan arus kas. Prediksi akrual berdasarkan arus kas dapat melengkapi atau menawarkan alternatif untuk pendekatan berbasis pendapatan jika perubahan pendapatan dan perubahan arus kas menangkap berbagai aspek akrual yang tidak dimodelkan oleh Dechow et al. (1998) dan / atau mewakili estimasi alternatif dari masalah waktu dan pencocokan (timing and matching) yang tidak dapat diobservasi yang menimbulkan akrual.

Menurut Frankel (2018) penelitian tentang memprediksi akrual berdasarkan properti arus kas, bertujuan untuk memahami peran cash flow timing and matching properties untuk menentukan akrual. Penerimaan dan pembayaran kas bersih dapat terjadi pada waktu dan periode yang berbeda dari peristiwa ekonomi (timing), dan perbedaan persyaratan pelunasan antara piutang dan utang yang dimiliki oleh perusahaan menyebabkan arus kas masuk atau arus kas keluar dari transaksi ekonomi dapat terjadi dalam periode yang berbeda pula (matching). Peran ekonomik akrual adalah untuk memitigasi isu timing and matching serta menghasilkan ukuran laba yang menyajikan relevansi nilai yang lebih baik.

Arus kas memiliki masalah waktu dan pencocokan (timing and matching) yang disebabkan oleh perbedaan waktu penerimaan dan pembayaran kas serta perbedaan persyaratan kredit antara piutang dan utang. Permasalahan yang ada pada arus kas ini membuat hasil pengukuran kinerja yang dilakukan oleh investor menjadi kurang tepat (Dechow, 1994). Peran ekonomi dari akrual adalah untuk mengurangi masalah waktu dan pencocokan, serta menghasilkan ukuran kinerja seperti pendapatan yang mencerminkan peristiwa yang relevan dengan nilai dari periode sekarang sampai periode masa depan. Dechow et al. (1998) menyebutkan bahwa kerangka kerja, waktu dan karakteristik pencocokan arus kas dapat menyebabkan korelasi serial dalam perubahan arus kas. Korelasi serial dalam perubahan arus kas 
terjadi karena adanya perbedaan waktu dalam pengeluaran kas dan penerimaan kas yang dihasilkan oleh perubahan penjualan dan pembelian, serta perbedaan persyaratan kredit antara piutang dengan hutang (timing and matching).

Penelitian-penelitian terdahulu yang terkait dengan memprediksi akrual dengan menggunakan properti arus kas diantaranya, penelitian yang dilakukan oleh Frankel (2018) tentang Predicting Accruals Based on Cash-Flow Properties, menunjukkan bahwa ada hubungan negatif antara akrual dan perubahan arus kas, dan menunjukkan bahwa kekuatan hubungan terkait dengan korelasi serial dalam perubahan arus kas yang negatif. Kemudian Frankel (2016) tentang Using Unstructured and Qualitative Disclosures to Explain Accruals, menunjukkan bahwa dalam memprediksi akrual dengan menggunakan properti arus kas memberikan bukti pertimbangan masalah arus kas secara substansial dapat meningkatkan kekuatan penjelas model akrual Jones (1991) dalam memprediksi akrual modal kerja. Frankel dan Yan Sun (2014) juga melakukan penelitian tentang predicting accrual based on problem with cash flow, hasilnya menunjukkan bahwa menambahkan perubahan arus kas dan perkiraan spesifik industri dari masalah arus kas ke model akrual secara substansial meningkatkan daya penjelas. Penelitian serupa juga dilakukan oleh Dechow (1994) yang menemukan bahwa akrual meningkatkan kemampuan laba untuk mengukur kinerja relatif terhadap arus kas.

Penelitian ini mengacu pada penelitian Frankel (2018) tentang kemampuan properti arus kas dalam memprediksi akrual pada perusahaan swasta di Amerika Serikat pada tahun 19892013. Penelitian ini dilakukan oleh Frankel (2018) untuk memahami sejauhmana sifat arus kas menjelaskan akrual, dengan menggunakan model Dechow et al. (1998). Motivasi peneliti untuk melakukan penelitian tentang memprediksi akrual ini adalah karena banyak peneliti sebelumnya mengatakan bahwa masih terbatasnya pengetahuan dan pemahaman dari berbagai pihak pengguna laporan keuangan tentang proses yang menghasilkan akrual (Owens et al., 2013; Ball, 2013). Ball (2013) juga mengatakan bahwa keterbatasan pengetahuan tentang faktor-faktor yang mempengaruhi akrual akan membuat rancangan riset tidak memadai untuk memprediksi akrual. Peneliti juga termotivasi untuk melakukan penelitian tentang akrual ini di Indonesia adalah untuk mengetahui bagaimana implikasi penelitian tentang sifat arus kas dalam menjelaskan akrual ini di Indonesia.

Penelitian ini bertujuan untuk menemukan bukti empiris apakah perubahan arus kas memiliki pengaruh dalam memprediksi akrual dan peran korelasi serial dalam perubahan arus kas dalam memoderasi hubungan perubahan arus kas dalam memprediksi akrual. Hasil penelitian ini diharapkan dapat menambah wawasan dan pengetahuan dalam memprediksi akrual, memberikan masukan dan pertimbangan untuk perusahaan dalam memprediksi akrual dengan memperhatikan perubahan arus kas dan korelasi serial dalam perubahan arus kas yang terjadi dalam perusahaan, dan hasil penelitian ini diharapkan dapat menambah literature dan ilmu pengetahuan peneliti selnajutnya tentang akrual.

\section{REVIU LITERATUR DAN HIPOTESIS \\ Teori agensi}

Teori ini mengemukakan masalah yang mungkin muncul antara pemegang saham dengan manager pengelola (agent). Setiap pihak dalam teori keagenan diasumsikan selalu bertindak untuk kepentingan dirinya sendiri terutama manajemen. Manajemen mempunyai informasi yang lebih lengkap dan rinci tentang perusahaan dibandingkan pemegang saham (asimetri informasi), yangmana asimetri informasi ini akan memicu konflik keagenan antara agent dan principal. 
Asumsi utama dari teori keagenan bahwa tujuan principal dan tujuan agent yang berbeda dapat memunculkan konflik karena manajer perusahaan cenderung untuk mengejar tujuan pribadi. Hal ini dapat mengakibatkan kecenderungan manajer untuk fokus pada proyek dan investasi perusahaan yang menghasilkan laba yang tinggi dalam jangka pendek daripada memaksimalkan kesejahteraan pemegang saham melalui investasi di proyek-proyek yang menguntungkan jangka panjang.

Teori agensi yang digunakan dalam penelitian relevan dengan penelitian tentang akrual, yang mana asumsi akrual ini digunakan oleh manajer perusahaan untuk meningkatkan kualitas laba perusahaan, yang akan mengindikasikan manajemen laba seperti hasil penelitian yang dilakukan oleh Frankel (2018). Penelitian Frankel (2018) menemukan bahwa pengetahuan tentang akrual dapat membantu investor dalam mendeteksi manajemen laba yang dilakukan oleh manajemen perusahaan. Teori agensi ini dapat memperlihatkan bagaimana tindakan manajemen dalam memilih sistem akuntansi yang akan diterapkan diperusahaan, selaku pihak agen yang diberi wewenang oleh principal. Tindakan oportunistik manajer yang ditimbulkan karena adanya konflik kepentingan ini dapat diprediksi dengan menggunakan properti arus kas untuk menjelaskan tingkat akrual yang terkandung didalam laporan keuangan. Properti arus kas yang digunakan adalah perubahan arus kas (cash flow change) yang mana dengan menggunakan komponen ini dapat memprediksi tingkat akrual yang terkandung dalam laporan keuangan yang disusun oleh manajer perusahaan.

\begin{abstract}
Akrual
Akrual merupakan besar penyesuaian akuntansi yang membuat laba bersih berbeda dari arus kas bersih. Sebagian besar perusahaan menggunakan akuntansi dasar akrual (accrual basis of accounting) untuk mengakui pendapatan ketika dihasilkan dan mengakui beban pada periode terjadinya, tanpa memperhatikan waktu penerimaan dan pembayaran kas. Dalam akuntansi berbasis akrual, pengakuan pendapatan atau beban diakui pada saat terjadinya bukan pada saat penerimaan atau pengeluaran kas (Kieso, 2007:105).

Dengan dasar akrual, seluruh transaksi dan peristiwa ekonomi yang terjadi diakui pada saat waktu terjadinya (bukan pada saat kas atau setara kas diterima atau dibayar) dan dicatat dalam catatan akuntansi serta dilaporkan dalam laporan keuangan pada periode yang bersangkutan. Laporan keuangan yang disusun atas dasar akrual memberikan informasi kepada pengguna laporan keuangan tidak hanya tentang transaksi masa lalu yang melibatkan penerimaan dan pembayaran kas, tetapi juga kewajiban pembayaran kas dimasa depan serta sumber daya yang mempresentasikan kas yang akan diterima di masa yang akan datang. Laporan keuangan yang disusun atas dasar akrual memberikan informasi kepada pengguna laporan keuangan tidak hanya tentang transaksi masa lalu yang melibatkan penerimaan dan pembayaran kas, tetapi juga kewajiban pembayaran kas dimasa depan serta sumber daya yang mempresentasikan kas yang akan diterima di masa yang akan datang. Elemen-elemen laporan keuangan dihitung dan dicatat dalam laporan keuangan melalui penggunaan prosedur akuntansi akrual. Akuntansi akrual didasarkan pada konsep akrual, tangguhan, alokasi, amortisasi, realisasi, dan pengakuan.
\end{abstract}

\title{
Perubahan Arus Kas
}

Menurut PSAK No. 2 paragraf 06 (IAI, 2018) arus kas adalah arus masuk kas dan arus keluar kas atau setara kas. Salah satu kegunaan informasi arus kas menurut PSAK No. 2 paragraf 04 (IAI, 2018) adalah meningkatkan daya banding kinerja operasi berbagai perusahaan karena dapat meniadakan pengaruh penggunaan perlakuan akuntansi yang berbeda terhadap transaksi dan 
peristiwa yang sama. Kemampuan arus kas untuk meningkatkan daya banding pelaporan kinerja operasi perusahaan ini merupakan salah satu alasan digunakannya arus kas sebagai sumber informasi oleh investor selain informasi laba yang disajikan oleh perusahaan untuk mengukur kinerja perusahaan.

Nilai yang ada didalam laporan arus kas pada suatu periode memberikan gambaran mengenai nilai laba dalam metode kas. Data akuntansi berdasarkan arus kas merupakan indikator keuangan yang lebih mencerminkan keadaan yang sebenarnya dibandingkan dengan akuntansi akrual karena arus kas sulit untuk dimanipulasi atau direkayasa oleh perusahaan (Fanani, 2010). Menurut Kieso at al. (2011) menyatakan arus kas dari aktivitas operasi adalah arus kas operasi mencakup pengaruh kas dari transaksi yang menghasilkan pendapatan dan beban, kemudian dimasukan dalam penentuan laba bersih. Arus kas dari aktivitas operasi, terutama diperoleh dari aktivitas utama perusahaan dalam memperoleh penghasilan. Oleh karena itu, arus kas tersebut pada umumnya berasal dari transaksi dan peristiwa ekonomi yang mempengaruhi penetapan laba atau rugi bersih perusahaan (Anif, 2016). Alasan digunakannya arus kas operasi dalam memprediksi akrual ini adalah karena arus kas operasi langsung terkait dengan aktivitas utama perusahaan dalam menghasilkan pendapatan. Aktivitas penghasil utama pendapatan perusahaan ini sangat erat kaitannya dengan asumsi yang digunakan oleh perusahaan dalam pengakuan transaksi ekonomi yang terjadi, sehingga akan langsung terkait dengan kebijakan akuntansi yang dipilih oleh perusahaan

\section{Korelasi Serial dalam Perubahan Arus Kas}

Penerimaan dan pembayaran kas bersih perusahaan dapat terjadi pada periode yang berbeda dari kejadian ekonomik (timing) dan arus kas masuk atau arus kas keluar dari peristiwa ekonomi tertentu dapat terjadi dalam periode yang berbeda (matching). Masalah timing dan matching yang ada pada arus kas ini akan menimbulkan korelasi serial dalam perubahan arus kas. Besarnya masalah timing dan matching pada arus kas ini dapat menentukan arah dan tingkat korelasi serial dalam perubahan arus kas. Dechow et al. (1998) menemukan bahwa korelasi serial dalam perubahan arus kas akan menjadi lebih negatif ketika besarnya margin laba bersih $(p)$ lebih kecil atau ketika siklus kas operasi (d) lebih lama.

\section{Penelitian Terdahulu}

Penelitian terdahulu yang meneliti tentang memprediksi akrual meggunakan property arus kas adalah penelitian yang dilakukan oleh Frankel (2018), Richard M. Frankel dan Yan Sun (2016), Maureen F. Mcnichlos (2002), S.P. Kothari, Andrew J. Leone, Charles E. Wasley (2005), Patricia M. Dechow, S.P. Kothari,Ross L. Watts (1998), Paul Hribrar, Daniel w Collins (2002), dengan ringkasan hasil penelitian sebagai berikut:

a. Perubahan arus kas memiliki hubungan yang negatif dalam memprediksi akrual, hubungan negatif ini akan menjadi negatif dengan adanya korelasi serial dalam perubahan arus kas yang negatif, dan menggunakan arus kas memiliki kekuatan penjelas untuk memprediksi akrual (Frankel, 2018; Richard M. Frankel dan Yan Sun ,2016; Patricia M. Dechow, S.P. Kothari,Ross L. Watts, 1998).

b. Penelitian yang berfokus pada akrual dengan menggunakan komponen arus kas dapat memberikan pemahaman yang lebih memadai tentang hubungan antara akrual dan arus kas, serta tentang kesalahan estimasi yang ada pada akrual (Maureen F. Mcnichlos, 2002; Paul Hribrar, Daniel w Collins, 2002). 
c. penelitian tentang akrual membantu meningkatkan keandalan kesimpulan dari penelitian tentang tindakan manajemen laba (S.P. Kothari, Andrew J. Leone, Charles E. Wasley 2005).

\section{Hubungan perubahan arus kas yang dimoderasi oleh korelasi serial dalam perubahan arus kas dalam memprediksi akrual}

Asumsi akrual memberikan gambaran tentang pengaruh transaksi dan peristiwa lain, keadaan sumber daya pelaporan entitas ekonomi, dan klaim pada periode dimana transaksi ekonomi tersebut terjadi, walaupun penerimaan dan pembayaran kas terjadi dalam periode yang berbeda. Akrual ini seringkali didasarkan pada asumsi dan esmasi yang tidak terlepas dari kesalahan estimasi. Kesalahan estimasi pada akrual dapat dikurangi dengan komponen arus kas, salah satunya adalah perubahan arus kas.

Perubahan arus kas merupakan jumlah kenaikan atau penurunan arus kas pada satu periode pelaporan akuntansi. Besarnya perubahan arus kas yang terjadi karena adanya perbedaan waktu dan masalah pencocokan (timing and matching), yang mana perbedaan waktu dan masalah pencocokan yang ada pada arus kas ini dapat diimbangi dengan akrual. Akrual mengimbangi fluktuasi arus kas yang terjadi selama periode berjalan, sehingga menimbulkan hubungan yang negatif antara perubahan arus kas dengan akrual.

Penelitian terdahulu menemukan bahwa terdapat hubungan negatif antara akrual dengan perubahan arus kas (R. M. Frankel \& Sun, 2018). Hubungan negatif antara akrual dengan perubahan arus kas ini menunjukkan bahwa arus kas mengandung komponen yang diimbangi oleh akrual. Komponen ini diwujudkan dalam periode yang berbeda antara realisasi kas yang diterima dari peristiwa ekonominya. Penerimaan kas atau pembayaran kas dapat terjadi pada periode yang berbeda dari peristiwa ekonomi (cash flow timing), serta arus kas masuk dan arus kas keluar dari peristiwa ekonomi tertentu dapat terjadi dalam periode yang berbeda (matching).

Kerangka kerja, waktu dan karakteristik pencocokan arus kas (cash flow timing and matching) dapat menyebabkan korelasi serial dalam perubahan arus kas. Menurut Frankel (2018) dengan adanya korelasi serial negatif dalam perubahan arus kas ini dapat meningkatkan atau menguatkan hubungan negatif yang ada antara akrual dengan arus kas. Penelitian yang dilakukan oleh Dechow (1998) juga menunjukkan bahwa terdapat hubungan atau korelasi yang negatif antara akrual dan perubahan arus kas, hubungan ini menjadi lebih negatif ketika terdapat korelasi serial dalam perubahan arus kas yang negatif. Semakin tinggi angka perubahan arus kas maka semakin rendah tingkat akrual yang ada dalam laporan keuangan perusahaan, sehingga akan mencerminkan kaulitas laba yang lebih baik.

Hasil penelitian yang dilakukan oleh Frankel (2018), Richard M. Frankel dan Yan Sun (2016) dan Patricia M. Dechow, S.P. Kothari,Ross L. Watts (1998), menunjukkan bahwa perubahan arus kas memiliki hubungan yang negatif dengan akrual, dan hubungan negatif ini menjadi lebih negatif karena adanya korelasi serial dalam perubahan arus kas yang negatif.

H1 : Perubahan arus kas berkorelasi negatif dengan tingkat akrual

H2 : Perubahan arus kas berkorelasi negatif dengan tingkat akrual, hubungan ini semakin negatif dengan adanya korelasi serial dalam perubahan arus kas yang negatif.

\section{METODE PENELITIAN}

\section{Jenis Penelitian}

Penelitian ini termasuk metode penelitian kuantitatif. Jenis penelitian yang dilakukan adalah asosiatif kausal dengan pendekatan kuantitatif. Penelitian asosiatif kausal adalah penelitian yang 
dilakukan untuk menganalisis hubungan antara satu variabel dengan variabel lainnya atau bagaimana suatu variabel memengaruhi variabel lain dalam suatu penelitian.

\section{Populasi dan sampel}

Populasi dalam penelitian ini adalah seluruh perusahaan manufaktur yang terdafyar di Bursa Efek Indonesia (BEI) tahun 2016 sampai 2018 yang berjumlah 167 perusahaan. Sampel diambil dengan menggunakan teknik purposive sampling dengan kriteria tertentu. Berdasarkan kriteria tersebut, sampel perusahaan yang menjadi fokus penelitian adalah sebanyak 43 perusahaan dengan 3 tahun pengamatan, sehingga total sampel pada penelitian ini berjumlah 129 sampel, dengan rincian sebagai berikut:

Tabel 1

Kriteria Pengambilan Sampel

\begin{tabular}{|l|l|}
\hline Keterangan & Jumlah \\
\hline $\begin{array}{l}\text { Perusahaan manufaktur yang tercatat di Bursa Efek } \\
\text { Indonesia tahun 2016-2018 }\end{array}$ & 167 \\
\hline $\begin{array}{l}\text { Perusahaan manufaktur yang tidak menyajikan laporan } \\
\text { keuangan secara lengkap dari tahun 2016-2018 }\end{array}$ & $(112)$ \\
\hline $\begin{array}{l}\text { Perusahaan manufaktur yang tidak menyajikan laporan } \\
\text { keuangan menggunakan mata uang rupiah dari tahun } \\
\text { 2016-2018 }\end{array}$ & \\
\hline Total sampel & 43 \\
\hline Periode pengamatan sampel 3 tahun $(3 \times 51)$ & 129 \\
\hline
\end{tabular}

(Sumber: www.idx.co.id, data diolah)

\section{Jenis dan Sumber Data}

Jenis data yang digunakan dalam penelitian ini adalah data sekunder. Data sekunder tersebut diambil dari laporan keuangan perusahaan manufaktur yang terdaftar di Bursa Efek Indonesia (BEI) dari tahun 2016 sampai 2018, yang telah dipublikasikan di situs web resmi Bursa Efek Indonesia (BEI) dan situs resmi masing-masing perusahaan. Laporan keuangan yang dimaksud adalah laporan keuangan yang mencakup laporan posisi keuangan, laporan laba rugi, laporan perubahan ekuitas, laporan arus kas dan catatan atas laporan keuangan.

\section{Variabel Penelitian dan Pengukuran Akrual}

Penelitian ini menggunakan model Dechow et al. (1998) yang telah diadopsi oleh Frankel (2018) untuk memprediksi akrual, yaitu dengan menggunakan akrual modal kerja. Persamaan yang digunakan untuk mengukur akrual:

\section{$\mathrm{ACCt}=(\Delta$ Account Receivable $+\Delta$ Inventory $-\Delta$ Account Payable $-\Delta$ Taxes Payable $+\Delta$ Other Assets) / Total Assets}

Dimana $\Delta$ Account Receivablet merupakan perubahan piutang dari tahun sebelumnya ke tahun berjalan. $\Delta$ Inventory merupakan perubahan persediaan dari tahun sebelumnya ke tahun berjalan, $\triangle$ Account Payable merupakan perubahan utang dari tahun sebelumnya ke tahun berjalan, $\Delta$ Taxes Payable, merupakan perubahan utang pajak dari tahun sebelumnya ke tahun berjalan, $\Delta$ Other 
Assets merupakan perubahan asset lainnya dari tahun sebelumnya ke tahun berjalan, dan Total Assets merupakan total asset tahun berjalan.

\section{Perubahan Arus Kas}

Pada penelitian ini arus kas yang digunakan adalah arus kas operasi. Menurut Noviyanto (2016) Jumlah arus kas yang berasal dari aktivitas operasi merupakan indikator yang menentukan apakah dari kegiatan operasi perusahaan dapat menghasilkan arus kas yang cukup untuk melunasi pinjaman, memelihara kemampuan operasi perusahaan, membayar dividen, dan melakukan investasi baru tanpa mengandalkan sumber pendanaan dari luar. Dalam penelitian ini Arus kas operasi diukur dengan menggunakan perubahan nilai arus kas operasi perusahaan i pada akhir periode $t$ dengan $\mathrm{t}-1$ dibagi dengan total aset pada tahun $\mathrm{t}-1$ yaitu sebagai berikut :

$$
\triangle C F O=C F O_{t}-C F O_{t-1} / \text { Total assets }
$$

Dimana $\triangle C F O t$ merupakan perubahan arus kas tahun berjalan. $C F O_{t}$ merupakan arus kas operasi tahun berjalan, $C F O_{t-1}$ merupakan arus kas operasi tahun sebelumnya dan Total assets merupakan total asset tahun berjalan.

\section{Korelasi Serial dalam Perubahan Arus Kas}

Korelasi serial dalam perubahan arus kas didefinisikan oleh Frankel (2018) sebagai rata-rata peringkat persentil dari siklus kas operasi rata-rata tiga tahun terakhir dan berbanding terbalik dengan peringkat persentil dari margin laba bersih rata-rata tiga tahun terakhir, dengan peringkat persentil terbentuk di setiap tahun. Siklus kas operasi dihitung dari piutang rata-rata dibagi dengan pendapatan bersih ditambah persediaan rata-rata dibagi dengan harga pokok penjualan dikurangi hutang rata-rata dibagi dengan pembelian. Margin laba bersih dihitung dari laba bersih dibagi dengan pendapatan bersih. Persamaan yang digunakan adalah sebagai berikut:

$$
\begin{aligned}
& r C Y C L E t=\frac{\text { Rata- rata Piutang }}{\text { Pendapatan Bersih }}+\frac{\text { Rata- rata Persediaan }}{H P P}-\frac{\text { Rata-rata Hutang lancar }}{\text { Pembelian }} \\
& N P M t=\text { laba bersih } / \text { pendapatan bersih }
\end{aligned}
$$

Dimana rCycle merupakan siklus kas operasi tahun berjalan, dan NPMt merupakan margin laba bersih tahun berjalan.

\section{Variabel kontrol}

Variabel kontrol (control variable) adalah variabel yang dikendalikan atau dibuat konstan sehingga hubungan variabel independen terhadap variabel dependen tidak terpengaruh oleh faktor-faktor lain yang tidak diteliti. Variabel yang memiliki korelasi dalam penelitian ini adalah perubahan pendapatan. Menurut Frankel (2018), penelitian yang memprediksi akrual juga dapat dilakukan dengan memperhatikan perubahan pendapatan yang terjadi pada suatu periode pelaporan.

Perubahan pendapatan adalah besarnya jumlah kenaikan atau penurunan jumlah pendapatan perusahaan dari tahun t-1 sampai ke tahun t. Perubahan pendapatan dapat dihitung dengan menggunakan rumus:

$$
\Delta R E V t=R E V_{t}-R E V_{t-1} / \text { Total Assets }
$$


Dimana $\triangle R E V t$ merupakan perubahan pendapatan tahun berjalan. $R E V_{t}$ merupakan pendapatan tahun berjalan, $R E V_{t-1}$ merupakan pendapatan tahun sebelumnya dan Total assets merupakan total asset tahun berjalan.

\section{Teknik Analisis Data}

Adapun tahap-tahap dalam melakukan analisis data pada penelitian ini adalah sebagai berikut:

\section{Analisis Deskriptif}

Analisis deskriptif yang digunakan dalam penelitian ini adalah untuk menginterpretasikan data rata-rata (mean), median, standar deviasi, nilai minimum, dan nilai maksimum.

\section{Analisis Induktif}

Metode yang digunakan dalam penelitian ini untuk menguji hipotesis penelitian adalah model regresi data panel. Model regresi data panel merupakan model yang melibatkan lebih dari satu variabel bebas (independen) dan terdiri dari beberapa tahun pengamatan.

Model yang digunakan pada penelitian ini adalah sebagai berikut:

Model 1:

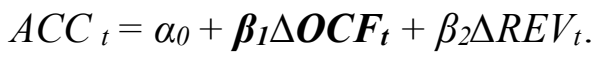

Model 1 digunakan untuk menguji pengaruh perubahan arus kas dalam memprediksi akrual. Dimana $\boldsymbol{\beta}_{1} \Delta \boldsymbol{O C \boldsymbol { F } _ { \boldsymbol { t } }}$ memberikan gambaran besaran pengaruh perubahan arus kas dalam memprediksi akrual.

Model 2:

$A C C_{t}=\alpha_{0}+\beta_{1} \Delta O C F_{t}+\beta_{2} \Delta O C F S C_{t}+\beta_{3} \Delta \boldsymbol{O C F}_{\boldsymbol{t}} * \Delta \boldsymbol{O C F S C} \boldsymbol{C}_{t}+\beta_{4} \Delta R E V_{t}+\varepsilon t \ldots$ (2)

Model 2 digunakan untuk menguji pengaruh korelasi serial dalam perubahan arus kas terhadap


memberikan gambaran besaran pengaruh korelasi serial dalam perubahan arus kas yang memoderasi hubungan perubahan arus kas dalam memprediksi akrual.

\section{HASIL DAN PEMBAHASAN}

\section{Analisis Deskriptif}

Hasil analisis deskriptif variabel yang digunakan pada penelitian ini adalah sebagai berikut:

\section{Tabel 2}

Statistik Deskriptif

\begin{tabular}{|c|r|r|r|r|r|}
\hline \multicolumn{7}{|c|}{ Deskriptive statistic } \\
\hline Variabel & \multicolumn{1}{|c|}{ Mean } & \multicolumn{1}{c|}{ Median } & \multicolumn{1}{c|}{ Maximum } & \multicolumn{1}{c|}{ Minimum } & \multicolumn{1}{c|}{ Std. Deviasi } \\
\hline ACCt (Y) & 0,0233 & 0,0148 & 1,0341 & -0.9168 & 0,1613 \\
\hline$\Delta$ CFO (x1) & 0,0025 & 0,0036 & 0,3121 & -0.3273 & 0,0807 \\
\hline OCFSC (z) & $-0,094$ & 2,1823 & 83,6000 & $-380,8309$ & 45,8979 \\
\hline$\Delta$ REV (x2 / control) & 0,0593 & 0,0591 & 1,1771 & $-0,8173$ & 0,2100 \\
\hline
\end{tabular}

(Sumber: Data Olahan E-views 10, 2020) 
Berdasarkan tabel diatas, variabel akrual (ACCt) sebagai variabel dependen memiliki rata-rata sebesar 0,0233 dengan standar deviasi 0,1613. Nilai akrual (ACCt) maksimum sebesar 1,0341 dan nilai minimum sebesar -0,9168. Variabel perubahan arus kas $(\Delta \mathrm{CFO})$ sebagai variabel independen memiliki rata-rata 0,0025 dengan standar deviasi 0,0807. Nilai $\triangle$ CFO maksimum sebesar 0,3121 dan nilai minimum sebesar -0,3273. Variabel korelasi serial dalam perubahan arus kas (OCFSC) sebagai variabel moderasi memiliki rata-rata -0,0948 dengan standar deviasi 45,8979. Nilai OCFSC maksimum sebesar 83,6000 dan nilai minimum sebesar -380,8309. Variabel kontrol terdiri dari satu variabel yaitu perubahan pendapatan ( $\triangle$ REV). perubahan pendapatan $(\triangle \mathrm{REV})$ memiliki rata-rata 0,0593 dengan standar deviasi 0,2100 . Nilai $(\triangle \mathrm{REV})$ maksimum sebesar 1,1771 dan nilai minimum sebesar $-0,8173$.

\section{Analisis Induktif}

\section{Estimasi model regresi}

Untuk mengetahui model yang tepat untuk dalam pengolahan data penelitian, maka dilakukan uji Chow test dan hausman test. Berikut hasil Chow test dan hausman test untuk variabel penelitian:

Tabel 3

Hasil Chow Test atau Likelyhood Test

\begin{tabular}{|c|c|c|c|}
\hline \multicolumn{4}{|c|}{ Cross Section Chi-Square } \\
\hline Model Penelitian & Statistic & d.f & Prob \\
\hline Model 1 & 11,6629 & 42 & 1,0000 \\
\hline Model 2 & 11,1075 & 42 & 1,0000 \\
\hline
\end{tabular}

(Sumber: Data Olahan E-views 10, 2020)

Berdasarkan tabel hasil Chow Test pada dua model penelitian diatas dengan menggunakan Eviews 10, didapat probabilitas sebesar 1,0000. Nilai probabilitasnya lebih besar dari level signifikansi $(\alpha=0,05)$ maka $\mathrm{H}_{\mathrm{a}}$ untuk model ini ditolak dan $\mathrm{H}_{0}$ diterima, sehingga estimasi yang lebih baik digunakan adalah Common Effect Model (CEM), sehingga dilanjutkan ke Hausman Test.

Berdasarkan hasil Chow Test atau Likelyhood Test pada Tabel 2, maka dibutuhkan uji Hausman pada persamaan regresi untuk hipotesi pertama (Model 1) dan hipotesis kedua (Model 2). Adapun hasil Hausman test adalah sebagai berikut:

Tabel 4

Hasil Hausman Test

\begin{tabular}{|l|c|c|c|}
\hline \multicolumn{4}{|c|}{ Cross Section Random } \\
\hline Model Penelitian & Chi-Sq. statistic & Chi-Sq. d.f & Prob \\
\hline Model 1 & 0,0169 & 2 & 0,9916 \\
\hline Model 2 & 0,1047 & 4 & 0,9987 \\
\hline
\end{tabular}

(Sumber: Data Olahan E-views 10, 2020)

Berdasarkan hasil Hausman Test dengan menggunakan eviews10, Nilai probabilitas Model 1 dan Model 2 pada penelitian ini adalah sebesar 0,8712 dan 0,9560. Nilai probabilitasnya lebih besar dari level signifikansinya $(\alpha=0,05)$, maka $\mathrm{H}_{0}$ untuk model ini diterima dan $\mathrm{H}_{\mathrm{a}}$ ditolak, sehingga estimasi yang lebih baik digunakan dalam penelitian ini adalah Random Effect Model (REM), sehingga tidak perlu dilakukan uji asumsi klasik. 


\section{Hasil Regresi Panel}

Berdasarkan hasil estimasi model regresi pada Chow Test (Tabel 2) dan Hausman Test (Tabel 3), maka digunakan pendekatan random effect model (REM) untuk mengestimasi pengaruh perubahan arus kas dalam memprediksi akrual (Model 1) dan pengaruh korelasi serial dalam perubahan arus kas terhadap hubungan arus kas dengan akrual (Model 2). Adapun hasil regresi panel dengan menggunakan pendekatan random effect model effect untuk regresi model 1 dan model 2 pada penelitian ini dapat dilihat pada Tabel 4 berikut:

Tabel 5

Hasil Regresi Panel

\begin{tabular}{|c|c|c|c|c|}
\hline \multicolumn{5}{|c|}{$\begin{array}{c}\text { Persamaan Regresi Model } 1 \\
\mathrm{ACC}_{\mathrm{t}}=\alpha_{0}+\beta_{1} \Delta \mathrm{OCF}_{\mathrm{t}}+\beta_{2} \Delta \mathrm{REV}_{\mathrm{t}}\end{array}$} \\
\hline \multicolumn{5}{|c|}{$\begin{array}{c}\text { Persamaan Regresi Model 2 } \\
\mathrm{ACC}_{\mathrm{t}}=\alpha_{0}+\beta_{1} \Delta \mathrm{OCF}_{\mathrm{t}}+\beta_{2} \Delta \mathrm{OCFSC}_{\mathrm{t}}+\beta_{3} \Delta \mathrm{OCF}_{\mathrm{t}} * \Delta \mathrm{OCFSC}_{\mathrm{t}}+\beta_{4} \Delta \mathrm{REV}_{\mathrm{t}}+\varepsilon \mathrm{t}\end{array}$} \\
\hline Variabel & & Prediksi & model 1 & model 2 \\
\hline \multirow{2}{*}{ Konstanta } & coef. & & 0,0170 & 0,0177 \\
\hline & t-stat & & 1,0193 & 1,0449 \\
\hline \multirow{2}{*}{$\Delta \mathrm{CFOt}$} & coef. & \multirow{2}{*}{ - } & $-0,4650 * *$ & $-0,4874 * *$ \\
\hline & t-stat & & $-2,3112$ & $-2,3161$ \\
\hline \multirow{2}{*}{ OCFSCt } & coef. & & - & 0,0001 \\
\hline & t-stat & & - & 0,3535 \\
\hline \multirow{2}{*}{$\Delta \mathrm{CFOt} * \mathrm{OCFSCt}$} & coef. & \multirow{2}{*}{ - } & - & 0,0041 \\
\hline & t-stat & & - & 0,4645 \\
\hline \multirow{2}{*}{$\triangle \mathrm{REVt}$} & coef. & \multirow{2}{*}{+} & $0,1245^{*}$ & $0,1187^{*}$ \\
\hline & t-stat & & 1,6106 & 1,5146 \\
\hline Adjusted R-Square & & & 0,0596 & 0,0526 \\
\hline F-Statistic & & & $0,0076 * * *$ & $0,0297 * *$ \\
\hline \multicolumn{5}{|c|}{$\begin{array}{l}\text { Keterangan : } \\
\Delta \text { CFOt } \quad: \text { Perubahan arus kas } \\
\text { OCFSCt: Korelasi serial dalam perubahan arus kas } \\
\Delta \text { REV t } \quad: \text { Perubahan pendapatan } \\
\text { n } \\
* * *, * * * * \text { signifikan pada } 1 \%, 5 \%, 10 \%\end{array}$} \\
\hline
\end{tabular}

(Sumber: Data Olahan E-views 10, 2020)

Hasil estimasi model regresi dengan pendekatan Random Effect Model (REM) pada tabel 4 diatas, diketahui bahwa besaran pengaruh perubahan arus kas dalam memprediksi akrual (model 1) diwakili oleh koefisien regresi $\triangle$ CFOt. Dimana berdasarkan Tabel 4 diketahui koefisien regresi $\triangle \mathrm{CFOt}$ adalah sebesar $-0,4650$. Hal ini berarti adanya pengaruh perubahan arus kas tahun berjalan dalam memprediksi akrual sebesar 0,4650 atau 46,50\% dan negatif. Hasil Adj R-square sebesar 0,0596 yang berarti seluruh variabel dependen berpengaruh terhadap variabel independen pada model 1 sebesar 0,0596 atau 5,96\%.

Hasil estimasi model regresi dengan pendekatan Random Effect Model (REM) untuk mengestimasi pengaruh korelasi serial dalam perubahan arus kas dalam memoderasi hubungan perubahan arus kas dalam memprediksi akrual (Model 2). Adapun hasil regresi panel dengan menggunakan pendekatan Random Effect Model (REM) untuk model 2 dapat dilihat pada Tabel 4. Berdasarkan tabel 4 diatas, dapat diketahui besaran pengaruh korelasi serial dalam perubahan 
arus kas yang memoderasi hubungan perubahan arus kas dalam memprediksi akrual diwakili oleh koefisien regresi $\triangle$ CFOt x OCFSCt. Dimana berdasarkan tabel 4 diketahui koefisien regresi $\triangle$ CFOt x OCFSCt adalah sebesar 0,0041 namun pengaruhnya tidak signifikan. Hasil Adj Rsquare sebesar 0,0526 yang berarti seluruh variabel bebas berpengaruh dalam memprediksi akrual sebesar 0,0526 atau $5,26 \%$.

\section{Uji Model}

Berdasarkan hasil regresi pada Tabel 4 diketahui bahwa, pada Model 1 nilai adjusted R2 yang diperoleh sebesar 0,0596 atau 5,96\%. Hal ini mengindikasikan bahwa kontribusi variabel independen terhadap variabel dependen sebesar 5,96\% dan sebesar 94,04\% ditentukan oleh variabel lain yang tidak dianalisis dalam model pada penelitian ini. Model 2 nilai adjusted R2 yang diperoleh sebesar 0,0526 atau 5,26\%. Hal ini mengindikasikan bahwa kontribusi variabel independen terhadap variabel dependen sebesar 5,26\% dan sebesar 94,74\% ditentukan oleh variabel lain yang tidak dianalisis dalam model pada penelitian ini.

Uji $\mathrm{F}$ digunakan untuk menguji secara bersama-sama pengaruh variabel independen terhadap variabel dependen, apakah model yang digunakan dapat memberikan pengaruh signifikan atau tidak yang dapat dilihat dari probabilitas (F-statistic). Jika F-stat lebih besar dari nilai kritis artinya variabel independen dalam model persamaan tersebut secara bersama-sama tidak berpengaruh signifikan terhadap variabel dependen dan sebaliknya. Berdasarkan tabel 10, model 1 memiliki nilai probabilitas (F-statistic) $<0,05=0,0076$ sehingga dapat disimpulkan bahwa variabel independen dalam model persamaan tersebut secara bersama-sama berpengaruh signifikan terhadap variabel dependen. Model 2 memiliki nilai probabilitas $(F$-statistic) $<0,05=$ 0,0297 sehingga dapat disimpulkan bahwa variabel independen dalam model persamaan ini secara bersama-sama juga berpengaruh signifikan terhadap variabel dependen.

Uji $\mathrm{t}$ digunakan untuk mengetahui pengaruh masing-masing variabel independen berpengaruh terhadap variabel dependen, apakah model yang digunakan dapat memberikan pengaruh signifikan atau tidak. Pada model regresi pertama, dilakukan estimasi pada pengaruh perubahan arus kas dalam memprediksi akrual yang disimbolkan dengan $\triangle \mathrm{OCF}_{\mathrm{t}}$. Berdasarkan tabel 4 diketahui bahwa koefisien $\triangle \mathrm{OCF}_{\mathrm{t}}$ bernilai negatif dan nilai prob sebesar 0,0224 . Hal ini berarti perubahan arus kas tahun berjalan berpengaruh signifikan negatif dalam memprediksi akrual, karena nilai prob $<0,05$, yaitu $0,0224<0,05$. Berdasarkan hasil regresi dari model pertama dapat disimpulkan bahwa hipotesis pertama diterima. Dimana hipotesis pertama berbunyi "perubahan arus kas berkorelasi negatif dengan tingkat akrual".

Model persamaan regresi kedua merupakan model persamaan regresi yang digunakan untuk mengestimasi pengaruh korelasi serial dalam perubahan arus kas yang memoderasi hubungan perubahan arus kas dalam memprediksi akrual. Pada model regresi kedua, dilakukan estimasi pada pengaruh korelasi serial dalam perubahan arus kas yang memoderasi hubungan perubahan arus kas dalam memprediksi akrual yang disimbolkan dengan $\beta_{3} \Delta \mathrm{OCF}_{\mathrm{t}} \mathrm{x} \Delta \mathrm{OCFSC}_{\mathrm{t}}$. Berdasarkan Tabel 4 diketahui bahwa koefisien $\triangle O \mathrm{OCF}_{\mathrm{t}} \mathrm{x} \triangle \mathrm{OCFSC}_{\mathrm{t}}$ bernilai positif dengan nilai prob sebesar 0,6431. Hal ini berarti korelasi serial dalam perubahan arus kas tidak mampu memperkuat atau memperlemah hubungan perubahan arus kas dalam memprediksi akrual, karena nilai signifikansi $>0,05$ yaitu 0,6431 $>0,05$. Berdasarkan hasil regresi dari model kedua dapat disimpulkan bahwa hipotesis kedua ditolak. Dimana hipotesis kedua berbunyi "Perubahan arus kas berkorelasi negatif dengan tingkat akrual, hubungan ini semakin negatif dengan adanya korelasi serial negatif dalam perubahan arus kas". 


\section{Pembahasan \\ Pengaruh Perubahan Arus Kas Dalam Memprediksi Akrual}

Hipotesis pertama pada penelitian ini adalah perubahan arus kas berkorelasi negative dengan tingkat akrual, dimana semakin besar perubahan arus kas maka tingkat akrual yang ada dalam laporan keuangan semakin kecil. Variabel akrual pada penelitian ini dihitung dengan akrual modal kerja, kemudian variabel perubahan arus kas pada penelitian ini diukur dengan menggunakan $\triangle \mathrm{OCFt}$, yang dihitung dengan mengurangi arus kas pada tahun berjalan dengan arus kas tahun sebelumnya (Frankel, 2018).

Berdasarkan hasil penelitian pada perusahaan sektor manufaktur yang terdaftar di BEI pada tahun 2016-2018, ditemukan bahwa hipotesis (H1) diterima, hal ini menunjukkan bahwa perubahan arus kas berpengaruh signifikan negatif dalam memprediksi akrual, dimana semakin besar perubahan arus kas maka tingkat akrual yang ada dalam laporan keuangan. Hal ini dapat dilihat dari hasil regresi panel pada tabel 4, yang menunjukkan bahwa nilai signifikan dari variabel $\triangle$ OCFt lebih kecil dari $\alpha 0,05 \%$, yaitu $0,0224<0,05 \%$. Perubahan arus kas memiliki pengaruh dalam memprediksi akrual sebesar 0,0596 atau 5,96\%.

Pengaruh perubahan arus kas yang signifikan negatif mengindikasikan bahwa semakin tinggi perubahan arus kas pada sampel amatan, menunjukkan semakin rendah tingkat akrual modal kerjanya. Arus kas adalah aliran masuk atau keluar dari kas dan setara kas. Arus kas yang ada dalam laporan keuangan perusahaan dihasilkan dari penerimaan dan pembayaran kas untuk transaksi ekonomi perusahaan. Arus kas ini dapat meningkatkan daya banding kinerja operasi berbagai perusahaan, karena arus kas dapat meniadakan pengaruh penggunaan perlakuan akuntansi yang berbeda terhadap transaksi dan peristiwa yang sama. Informasi arus kas dalam laporan keuangan perusahaan merupakan indikator keuangan yang lebih mencerminkan keadaan yang sebenarnya dibandingkan dengan informasi akrualnya, karena arus kas sulit untuk dimanipulasi atau direkayasa oleh perusahaan. Sedangkan akrual mengakui seluruh transaksi dan peristiwa ekonomi yang terjadi pada saat waktu terjadinya dan bukan pada saat kas atau setara kas diterima atau dibayarkan, serta dicatat dan dilaporkan dalam laporan keuangan pada periode yang bersangkutan.

Hasil penelitian ini konsisten dengan hasil penelitian yang dilakukan oleh Frankel (2018) tentang Predicting Accruals Based on Cash-Flow Properties, menunjukkan bahwa ada hubungan negatif antara akrual dan perubahan arus kas. Kemudian hasil penelitian ini juga konsisten dengan penelitian yang dilakukan oleh Dechow (1998). Semakin tinggi angka perubahan arus kas sampel amatan maka semakin rendah tingkat akrual modal kerja yang ada dalam laporan keuangan perusahaan, sehingga akan mencerminkan kualitas laba yang lebih baik.

Menurut Frankel (2018) hubungan yang negatif antara perubahan arus kas dengan akrual ini menunjukkan bahwa arus kas mengandung komponen yang diimbangi oleh akrual, karena komponen ini diwujudkan dalam periode yang berbeda dari peristiwa ekonomi yang terjadi seperti penjualan kredit yang pelunasannya belum diterima pada periode berjalan.

Berdasarkan hasil penelitian, maka dapat disimpulkan bahwa semakin besar perubahan arus kas yang dimiliki perusahaan yang diukur dengan membandingkan arus kas tahun berjalan dengan tahun sebelumnya, maka akan memberikan gambaran bahwa tingkat akrual yang ada dalam laporan keuangan suatu perusahaan rendah. Hal tersebut terjadi karena ketika penerimaan dan pembayaran kas untuk transaksi ekonomi perusahaan yang perubahannya besar maka hal tersebut menandakan tingkat akrual yang terkandung dan disajikan dalam laporan keuangan menjadi lebih rendah. 
Perusahaan yang dapat mengelola kasnya dengan baik pada suatu periode akan memberikan manfaat bagi pengguna laporan keuangannya untuk menilai kinerja perusahaan. Nilai yang ada didalam arus kas memberikan gambaran mengenai nilai laba dalam metode kas. informasi arus kas dalam laporan keuangan merupakan indikator keuangan yang lebih mencerminkan keadaan yang sebenarnya dibandingkan dengan akuntansi akrual karena arus kas sulit untuk dimanipulasi atau direkayasa oleh perusahaan. Kemudian dengan komponen arus kas ini pengguna laporan keuangan dapat menilai seberapa besar akrual yang terkandung di dalam laporan keuangan suatu perusahaan.

\section{Pengaruh Korelasi Serial Dalam Perubahan Arus Kas Yang Memoderasi Hubungan Perubahan Arus Kas Dalam Memprediksi Akrual}

Hipotesis kedua dalam penelitian ini adalah Perubahan arus kas berkorelasi negatif dengan tingkat akrual, hubungan ini semakin negatif dengan adanya korelasi serial dalam perubahan arus kas yang negatif. Variabel korelasi serial dalam perubahan arus kas dihitung menggunakan rank persentil siklus kas operasi dan kebalikan rank persentil margin laba bersih sesuai dengan penelitian yang telah dilakukan oleh Frankel (2018).

Berdasarkan hasil uji hipotesis kedua, ditemukan dalam penelitian ini bahwa hipotesis kedua ditolak. Hasil penelitian ini tidak membuktikan bahwa korelasi serial dalam perubahan arus kas memperkuat atau memperlemah hubungan antara perubahan arus kas dengan akrual. Hal ini dapat dilihat dari hasil regresi panel pada tabel 4, yang menunjukkan bahwa nilai signifikasi variabel t yang tidak signifikan pada $\alpha 5 \%$, yaitu koefisien $\Delta \mathrm{OCF}_{\mathrm{t}} \mathrm{x} \Delta \mathrm{OCFSC}_{\mathrm{t}}$ bernilai positif dengan nilai prob sebesar 0,6431 atau 0,6431 >0,05. Hasil ini menunjukkan bahwa korelasi serial dalam perubahan arus kas tidak mampu memperkuat atau memperlemah hubungan perubahan arus kas dalam memprediksi akrual.

Hasil penelitian ini berbeda dengan hasil penelitian yang dilakukan oleh Frankel (2018). Hasil penelitian Frankel (2018) menemukan bahwa koefisien negatif yang signifikan untuk korelasi serial dalam perubahan arus kas. Temuan Frankel (2018) ini menunjukkan bahwa hubungan negatif antara perubahan arus kas dengan akrual menjadi lebih kuat karena korelasi serial dalam perubahan arus kas yang meningkat.

Menurut Frankel (2018) hubungan negatif antara perubahan arus kas dengan akrual yang diperkuat oleh korelasi serial dalam perubahan arus kas yang meningkat menunjukkan bahwa dalam arus kas terdapat masalah timing dan matching yang parah. Tapi dalam penelitian ini hubungan antara perubahan arus kas dengan akrual yang dimoderasi oleh korelasi serial dalam perubahan arus kas tidak menunjukkan hasil yang signifikan. Hasil ini menandakan bahwa pada arus kas yang ada dalam perusahaan manufaktur yang menjadi sampel penelitian ini tidak terdapat masalah timing dan matching yang parah, sehingga hipotesis kedua penelitian ini ditolak.

Beberapa faktor yang menyebabkan hipotesis kedua ditolak diantaranya adalah karena perusahaan yang menjadi sampel penelitian tidak mengungkapkan data pembelian bahan baku dan barang jadi secara keseluruhan, sehingga hasil utuk siklus kas operasi yang digunakan untuk mencari korelasi serial dalam perubahan arus kas menjadi tidak signifikan. Kemudian perusahaan manufaktur yang dijadikan sampel penelitian diambil secara keseluruhan dan tidak membedakan karakteristik masing-masing perusahaan, sehingga data yang digunakan menjadi sangat beragam terutama untuk data pembelian perusahaan. Data tahun pengamatan yang digunakan dalam pengambilan sampel penelitian cukup pendek hanya mencakup tiga tahun yaitu dari tahun 2016-2018, sehingga hipotesis kedua ditolak. Berdasarkan penelitian ini korelasi 
serial dalam perubahan arus kas merupakan variabel yang tidak berpengaruh terhadap perubahan arus kas dalam memprediksi akrual.

\section{KESIMPULAN, KETERBATASAN DAN SARAN Kesimpulan}

Penelitian ini bertujuan untuk melihat seberapa besar pengaruh korelasi serial dalam perubahan arus kas yang memoderasi hubungan perubahan arus kas dalam memprediksi akrual pada perusahaan manufaktur yang terdaftar di Bursa Efek Indonesia (BEI) pada tahun 2016-2018. Hasil penelitian ini menunjukkan bahwa perubahan arus kas berpengaruh signifikan negatif dalam memprediksi akrual, hal ini menunjukkan bahwa semakin besar perubahan arus kas yang ada diperusahaan menandakan bahwa tingkat akrual yang ada dalam laporan keuangannya semakin rendah. Kemudian penelitian ini juga menunjukkan bahwa korelasi serial dalam perubahan arus kas tidak dapat memperkuat atau memperlemah hubungan perubahan arus kas dalam memprediksi akrual pada perusahaan manufaktur yang terdaftar di Bursa Efek Indonesia tahun 2016 sampai 2018.

Implikasi dari penelitian ini bahwa perusahaan yang memiliki perubahan arus kas yang besar menandakan tingkat akrual yang ada dalam laporan keuangan perusahaan rendah. Hal tersebut terjadi karena ketika penerimaan dan pembayaran kas untuk transaksi ekonomi perusahaan yang perubahannya besar maka hal tersebut menandakan tingkat akrual yang terkandung dan disajikan dalam laporan keuangan menjadi lebih rendah. Penelitian ini juga memiliki implikasi bagi pemangku kepentingan dalam perusahaan terutama bagi investor. Bagi investor informasi tentang arus kas dapat berguna dalam pengukuran kinerja keuangan selain informasi laba yang disajikan dalam laporan keuangan perusahaan. Laporan arus kas dapat meningkatkan daya banding kinerja operasi berbagai perusahaan karena dapat meniadakan pengaruh penggunaan perlakuan akuntansi yang berbeda terhadap transaksi dan peristiwa yang sama.

\section{Keterbatasan}

Peneliti telah berusaha merancang dan mengembangkan penelitian sedemikian rupa, namun masih terdapat beberapa keterbatasan dalam penelitian ini yang masih perlu diperbaiki bagi peneliti selanjutnya, yaitu antara lain:

1. Tidak semua perusahaan yang dijadikan sebagai sampel penelitian menyajikan data pembelian bahan baku dan pembelian barang jadi pada laporan keuangannya, sehingga perhitungan data untuk siklus kas operasi (rCycle) menjadi terganggu dan perusahaan tersebut dikeluarkan dari sampel penelitian.

2. Penelitian ini baru memberikan gambaran mengenai akrual pada perusahaan manufaktur, sehingga data penelitian tidak dapat mewakili keseluruhan perusahaan pada BEI.

3. Tahun pengamatan yang digunakan dalam pengambilan sampel hanya mencakup 3 tahun yaitu dari tahun 2016-2018. Hal ini dikarenakan keterbatasan informasi dan keterbatasan data yang tidak lengkap.

\section{Saran}

Berdasarkan kesimpulan dan keterbatasan penelitian yang telah diuraikan sebelumnya, maka saran yang dapat peneliti berikan terkait dengan penelitian ini, yaitu:

1. Bagi peneliti selanjutnya diharapkan dapat menggunakan jenis perusahaan yang berbedabeda dan memakai ruang lingkup sampel yang lebih luas. 
2. Bagi peneliti selanjutnya diharapkan dapat menambah tahun pengamatan dengan meneliti lebih dari 3 tahun agar hasil yang diperoleh lebih berkualitas.

3. Bagi peneliti selanjutnya yang tertarik untuk meneliti judul yang sama, sebaiknya mempertimbangkan dan mencari variabel independen dan variabel moderasi lainnya yang berhubungan dengan akrual.

\section{DAFTAR PUSTAKA}

Al,Kieso et. (2007). Pengantar Akuntansi. Jakarta: Salemba Empat

Ball, R., and Shivakumar L (2006). The role of accruals in asymmetrically timely gain and loss recognition. Journal of Accounting Research 44 (2), 207-242.

Ball, R. (2013). Accounting Informs Investors and EarningsManagement is Rife: Two Questionable Beliefs. Accounting Horizons. 27 (4), 847-853

Dechow, Patricia M., dan Ilia D. D. (2002). The Quality of Accruals and Earnings: The Role of Accrual Estimation Errors. The Accounting Review, 77, 35-59.

Dechow, Patricia M., dan Ilia D. Dichev. (1998). The relation between earnings and cash flow. Journal of Accounting and Economics 25, 133-168

Dechow, Patricia M. (1994). Accounting earnings and cash flows as measures of firm performance The role of accounting accruals. Journal of Accounting and Economics 18, 342

Frankel, Richard .M dan Yan Sun. (2018). Predicting Accruals Based on Cash-Flow Properties. The Accounting Review. 93(5), 165-186.

Frankel, Richard et al. (2016). Using Unstructured and Qualitative Disclosures to Explain Accruals. Journal of Accounting and Economics

Fanani, Z. (2010). Analisis Faktor-Faktor Penentu Persistensi Laba. Jurnal Akuntansi dan Keuangan Indonesia, 7(1), 109 -123.

Hribar, Paul dan Daniel W, C. (2002). Errors in Estimating Accruals: Implications for Empirical Research. Jurnal of Accounting Research, 40 (1).

Ikatan Akuntansi Indonesia. PSAK No. 1 Tentang Laporan Keuangan - edisi revisi 2018. Penerbit Dewan Standar Akuntansi Keuangan: PT. Raja Grafin.

Ikatan Akuntansi Indonesia. PSAK No. 2 Tentang Laporan Arus Kas-edisi revisi 2018. Penerbit Dewan Standar Akuntansi Keuangan: PT. Raja Grafin.

Jones, J., (1991). Earnings management during import relief investigations. Journal of Accounting Research 29, 193-228.

Kothari, S., Leone, A., and Wasley, C. (2005). Performance matched discretionary accrual measures. Journal of Accounting and Economics 39, 163-197.

Kieso dan Weygandt. (2011). Intermediate Accounting edisi tahun 2011. Jakarta: Erlangga

Lam, Nelson dan Peter L. (2015). Akuntansi keuangan intermediate financial report . Ed 2.1 Jakarta: salemba empat.

Lam, Nelson dan Peter Lau. (2015). Akuntansi keuangan intermediate financial report . Ed 2.2 Jakarta: salemba empat.

Martini, Dwi dkk. (2016). Akuntansi Keuangan Menengah Berbasis PSAK . Ed 2.1 Jakarta: salemba empat.

McNichols, M. 2002. Discussion of The Quality of Accruals and Earnings: The Role of Accrual Estimation Errors. The Accounting Review, 77, 61-9. 
Noviyanto, A. (2016). Pengaruh Laba Bersih, Arus Kas Operasi, Dan Likuiditas Terhadap Kebijakan Dividen. Jurnal Profita, Edisi 8. Universitas Negeri Yogyakarta.

Sarifudin, A dan Sodiqin M. (2016). Pengaruh Arus Kas Operasi, Arus Kas Investasi, Arus Kas Pendanaan Dan Laba Bersih Terhadap Return Saham Pada Perusahaan Manufaktur Yang Terdaftar Di Bursa Efek Indonesia. Dharma Ekonomi, Nomor 43. STIE Dharmaputra Semarang.

Richardson, Scott A et al. (2005). Accrual reliability, earnings persistence and stock prices. Journal of Accounting and Economics 39 (2005) 437-485.

Scott, W.R. (2015). Financial Accounting. Canada: Pearson.

Subramanyam, K. R. 1996. The pricing of discretionary accruals. Journal of Accounting and Economics 22 (1996) 249-281.

Subramanyam, K.R Dan J.J. Wild. (2010). Analisis Laporan Keuangan. Edisi 10 Bukul .Jakarta : Salemba Empat

Suwardjono. (2005). Teori Akuntansi: Perekayasaan Pelaporan Keuangan. Yogyakarta: BPFE.

Warsono, Sony, et al. (2009). Konsep dan Model Corporate Governance. Yogyakarta: Center for Good Corporate Governance.

Wing, Winarno. 2009. Analisis Ekonometrika dan Statistika dengan Eviews. Edisi Kedua. Yogyakarta : UPP STIM YKPN 